\title{
PECULIARITIES OF FORMS AND METHODS OF EDUCATIONAL WORK OF THE PETROVSK POLTAVA CADET CORPS (1840-1919)
}

\section{ОСОБЛИВОСТІ ФОРМ І МЕТОДІВ НАВЧАЛЬНО-ВИХОВНОЇ РОБОТИ ПЕТРОВСЬКОГО ПОЛТАВСЬКОГО КАДЕТСЬКОГО КОРПУСУ (1840-1919)}

\section{Artem Inozemtsev ${ }^{1}$ \\ Larisa Semenovska ${ }^{2}$}

DOI: https://doi.org/10.30525/978-9934-26-001-8-1-4

Abstract. The article is devoted to one of the areas of military pedagogy cadet education. It describes the features of forms and methods of educational work in the Petrovsky Poltava Cadet Corps (1840-1919) - the first military educational institution in the Ukrainian provinces of the Russian Empire. The main activities of the Petrovsky Poltava Cadet Corps were: general and special military. General education provided the study of a wide range of subjects (the law of God, Russian language and literature, foreign languages, mathematical sciences, natural history, physics, chemistry, cosmography, geography, history, legislation, drawing, calligraphy), as well as religious, moral, aesthetic, physical, labor education, contributed to the intellectual development of cadets, the formation of honor and dignity, agility and endurance, instilled noble behavior. Pupils were also taught music (music theory, playing musical instruments, choral singing, secular work and spiritual music). Special military (military sciences, militaryphysical, military-training) was aimed at mastering the basics of military affairs, practical skills and the formation of the strength of spirit necessary for the military to perform its duties to protect the state. In the first twenty years of the institution's activity, the military element was the main one in

\footnotetext{
${ }^{1}$ Graduate Student of the Department of Pedagogy and Andragogy of

Poltava National Pedagogical University named after V.G. Korolenko, Ukraine

${ }^{2}$ Doctor of Pedagogical Sciences,

Professor of the Department of Pedagogy and Andragogy of

Poltava National Pedagogical University named after V.G. Korolenko, Ukraine
} 
the training of cadets, and its basis was considered to be military training. It practiced at least 6 hours a week and spent the same amount of time on fencing and gymnastics. The foundations of military affairs were laid during the mastering of courses artillery, fortification, tactics and military topography. The factual material presented in the article proves that the forms (lessons, additional classes, subject groups, independent work, control test, exams, excursions, stay in the summer camp) and methods of educational work in the Petrovsky Poltava Cadet Corps contributed to the formation of a comprehensively developed personality of the cadet, devoted to military affairs and the state. One of the methods of education in the Petrovsky Poltava Cadet Corps was the method of training. The implementation of this method primarily contributed to the formation and rooting in the cadets of one of the most important in their future work traits such as discipline. Cadets were also taught to read (independent and group). It included: conversations, reading of works of classics, pedagogical situations, educational reading of periodicals with the subsequent discussion. The functioning of cadet corps and lyceums with enhanced physical training in modern Ukraine, based on the principles of cadet education, is the basic basis for the formation of highly qualified officers of the Armed Forces of Ukraine. Thus, recourse to the experience of military pedagogy is relevant.

\section{1. Ветуп}

Сучасна ситуація в Україні, яка пов'язана з війною на Сході, потребує активізації заходів щодо підвищення обороноздатності держави, формування високопрофесійних, мобільних та боєздатних Збройних Сил, ставить питання розробки сучасної стратегії військової освіти, де було б враховано всі досягнення військової педагогіки попереднього часу.

Серед сучасних практик підготовки військових в Україні своє важливе місце займають ліцеї з посиленою фізичною підготовкою та сучасні кадетські корпуси, діяльність яких відбувається з урахуванням кращих традицій та досвіду функціонування військово-навчальних закладів, що були створені на території українських губерній Російської імперії і зіграли важливу роль у підготовці офіцерських кадрів у другій половині XIX - на початку XX століття. Серед них Петровський Полтавський кадетський корпус (1840-1919) - перший військовий заклад на українських землях. 
Військова педагогіка відрізняється від решти педагогічних галузей безпосереднім залученням об'єктів виховання й навчання в реальну професійну діяльність, пов'язану з вирішенням відповідальних задач, які потребують високих морально-психологічних якостей, готовності, вишколу та здатності діяти в складних обставинах, також і з ризиком для життя [4, с. 67].

Специфіку військової педагогіки в повній мірі вже на самому початку XX ст. відтворювали кадетські корпуси. Полковник Російської Армії В. Райковський у статті «Військове виховання», стверджує, що ці навчальні заклади приносять велику користь у справі підготовки командного складу армії: «Контингенти корпусів, що виховуються й ведуться з юних років, створюють те, чого жодний навчальний заклад іншого типу зробити не в змозі. Кадетські корпуси, які витримуються в строгому порядку, системі, режимі, виховуючи спартанські звички, виховуючи і характер і волю, поки лише одні дають найкращий матеріал для заповнення проломів, що утворюються через природну втрату командного складу в армії...» [25, с. 266].

Щодо етапів розвитку Петровського Полтавського кадетського корпусу, то ми вважаємо доцільним виділити три, відповідно до статусу, змісту навчання та напрямків діяльності.

I етап (1840-1865 роки) - заснування корпусу та початковий етап його розвитку в умовах завершення процесу формування в державі системи централізованого управління військовою освітою. Саме військова справа посідала головне місце у навчанні кадетів, а її основним предметом вважалася стройова підготовка.

II етап (1865-1882 роки) - етап реформування Петровського Полтавського корпусу у військову гімназію, зміщення акцентів у підготовці майбутніх офіцерів на загальноосвітній напрям та нову парадигму військової педагогіки, яка сформувалася у цей час як наука.

III етап (1882-1919 роки) - етап зворотної реорганізація військової гімназії у кадетський корпус, поновлення та посилення військового напряму у підготовці вихованців корпусу до військової служби, вдосконалення навчального та виховного процесів та перетворення Петровського Полтавського кадетського корпусу в один із престижних військових навчальних закладів Російської імперії. 
Отже, мета нашого наукового пошуку довести, що форми і методи навчально-виховної роботи у Петровському Полтавському кадетському корпусі були спрямовані на формування всебічно розвиненої особистості кадета, відданої військовій справі та державі.

У своєму дослідженні ми спиралися на такі методологічні основи. Методи науково-педагогічних досліджень, як шляхи вивчення складних психолого-педагогічних процесів формування особистості, встановлення об'єктивних закономірностей процесів виховання і навчання. Методи одержання ретроспективної інформації шляхом вивчення науково-педагогічної літератури, архівних документів, мемуарів, які характеризують організаційно-педагогічні засади діяльності Петровського Полтавського кадетського корпусу, дають уявлення про предмет нашого дослідження, а саме особливості навчально-виховного процесу у Петровському Полтавському кадетському корпусі та його компоненти. До компонентів навчально-виховного процесу ми відносимо: загальноосвітній та військовий напрям навчання кадетів, привчання до читання, музичне виховання, перебування у літньому таборі, релігійне виховання. Тож розкриємо зміст кожного з них.

\section{2. Загальноосвітній та військовий напрям навчання кадетів}

Основними напрямами в діяльності Петровського Полтавського кадетського корпусу були: загальноосвітній і спеціальний військовий. Загальноосвітній напрям передбачав вивчення широкого спектру навчальних предметів, а також релігійне, моральне, естетичне, фізичне, трудове виховання, сприяв інтелектуальному розвитку кадетів, формуванню честі й гідності, спритності і витривалості, прищеплював благородну поведінку. Спеціальний військовий (військові науки, військово-фізична, стройова підготовка) був спрямований на засвоєння основ військової справи, практичних навичок та формування сили духу, необхідних військовому для виконання своїх обов'язків по захисту держави.

Система навчання у кадетському корпусі регулювалась нормами п’ятої глави «Навчання в кадетських корпусах» Положення про кадетські корпуси. У п.31 вказано: «Навчання в кадетських корпусах повинне поступово розвивати розумові здібності учнів і повідомляти їм грунтовні знання істин Віри і освітніх предметів, необхідних для подальшої їх освіти, так і для подальшої їх службової і життєвої діяльності» [24, с. 25]. 
Формування професійних вмінь та навичок кадетів здійснювалося у створеній викладачами корпусу атмосфері, що грунтувалася на вимогливості, з одного боку, та гуманному ставленні і повазі до вихованців, з іншого боку, співтворчості викладачів та вихованців, що сприяло формуванню критичного мислення у майбутніх військових. У спогадах випускника А.Б. Меньшого зазначається: «Мої вчителі, люди з університетською освітою, горіли любов'ю до знань, які вони викладали, весь центр тяжіння зосереджували на прищепленні прагнення та поваги до цих занять у своїх учнів» [19, с. 17].

Загальний термін навчання в корпусі періодично змінювався. У 40-ві роки XIX-го століття повний курс кадетської освіти був восьмирічним і складався з трьох відділів: підготовчого (2 роки), загального (4 роки) та спеціального (2 роки). У 1857 році у корпусі були введені спеціальні класи, де кадети здобували кінцеву освіту і направлялися прапорщиками в піхоту, інженерні війська, а також у батальйони внутрішньої варти [21, с. 81].

У військовій гімназії був встановлений шестирічний курс навчання, однак у 1873-1874 навчальному році заклад перейшов на семирічний курс, по одному року в кожному класі [22, с. 54]. Саме семирічний курс навчання залишився в Полтавському корпусі до кінця його існування.

У корпусі наприкінці 1850-х років викладали такі загальні дисципліни: Закон Божий, російська, французька і німецька мови, чистописання і малювання, математика (арифметика, тригонометрія, геометрія, алгебра), географія, законознавство, фізика, ботаніка з зоологією, малювання (креслення). [35, арк. 24-25].

На спеціальному курсі вивчали: Закон Божий, мови, історію, законознавство, математику та хімію. Додавалося вивчення статистики i низки військових дисциплін [8, арк. 14-16; 36, арк. 18-19].

Процесу військової підготовки кадетів у повній мірі сприяла атмосфера, яка панувала у корпусі. Його вихованець О. Бутовський згадував: «Усі ми були оточені лише військовим елементом. Сама атмосфера відпрацьовувала в нас ультрастройові інстинкти» [3, с. 330-331].

У перші двадцять років діяльності закладу військовий елемент був головним у підготовці кадетів, а його основою вважалася стройова підготовка, яку називали «фронтовим навчанням». Нею займалися не менше 6 годин на тиждень й стільки ж часу відводилося на фехтування і гімнастику [21, с. 29]. 
У спеціальних класах основи військової справи закладалися під час засвоєння курсів з артилерії, фортифікації, тактики та військової топографії [16, с. 69].

Під час гімназійного періоду основою військової підготовки юнаків стала гімнастика. За загальним розкладом на стройові заняття протягом тижня було визначено для молодшого віку - 2 години, для вихованців старшого віку - по 1 годині. Навчання проводилося поетапно, спочатку одиночна підготовка, потім стройові прийоми у складі відділення. Для зменшення кількості стройових занять вихователі протягом дня слідкували, щоб вихованці рухались у складі підрозділів стройовим кроком під час пересувань. Першокласники вчилися пересуватися бігом під удар барабана, починаючи з другого класу - поодиноким стройовим прийомам, потім рядами та шеренгами і закінчували маршируванням у складі відділення. Піхотним сигналам вчили попередньо на голос, за допомогою вчителя співу [17, с. 592-593].

Головна увага керівництва навчального закладу приділялася підтриманню військової дисципліни та порядку. У перші десятиріччя існування закладу виховні прийоми були примітивними і зводилися до прищеплення учням почуття страху за будь-які порушення через покарання, серед яких широко практикувалися тілесні. Це призвело до значної кількості порушень дисципліни, насамперед проявів неповаги до старших. Найбільш резонансним виглядав кадетський бунт 1860 року, коли кадети відмовилися виконувати накази своїх командирів і директора закладу. Спроби керівництва швидко навести порядок призвели до масових безладів.

На виправлення такого стану керівництво закладу витрачало чимало сил вже за часів військової гімназії. Вживалися різноманітні заходи попереджувального та виправного характеру, але новизною стало те, що вихователі вже намагалися не карати, а оберігати юнаків від вчинків, використовуючи заходи педагогічного впливу. Ось витяг із засідання Педагогічного комітету, що характеризує загальні погляди його членів: «Досвід показав, що і найбільшого пустуна не слід вважати невиправним. Нерідко його молода натура, віддавши данину вікові, змінюється на краще. У такий момент безпідставне стягнення може подіяти на неї вкрай шкідливо, охолоджуючи в вихованці бажання виправити свою репутацію» [18, с. 76-77]. 
Важливу роль у розбудові кадетської освіти відіграв один із кращих керівників Петровського Полтавського кадетського корпусу генерал-лейтенант Ф.І. Сімашко (був директором корпусу з 1865 до 1885 року), який скасував принизливі покарання, - звичай ставити в кут, заносити прізвище вихованця на чорну дошку, обмежувати в їжі. Звичайно, навіть найбільш правильні педагогічні дії керівництва не могли припинити типові дитячі пустощі, але серйозних проблем дисциплінарного характеру, таких як бунти 60-х років XIX століття, вже не виникало.

У Петровському Полтавському кадетському корпусі традиційно проводились екзамени. Рівень знань кадетів перевірявся під час складання річних екзаменів. У «Матеріалах» Ромашкевича вказано: «Річні екзамени були ті, що і в минулому році. У 7 класі екзамени тривали 3 9 квітня до 24 травня, в 6 - 312 до 29 травня, в 5 - з 12до 24 травня, в 4 - 39 до 24 травня і в 3 - 12 до 19 травня.» Прийом вихованців на навчання у корпусі проводився за підсумками вступних екзаменів. У 1912 році «Вступні екзамени були 29, 30 і 31 травня та 9,10 та 11 серпня.» Переекзаменування проводилось 13 та 14 серпня [27, с. 16].

Отже, загальноосвітній та спеціальний військовий напрями діяльності Петровського Полтавського кадетського корпусу були спрямовані на формування у вихованців навичок стійкого і глибокого засвоєння знань із спеціальних та суспільних дисциплін; розвиток у майбутніх військових творчого, аналітичного мислення; здатності до творчої роботи за фахом; розширенні кругозору; виробленні вміння залучати теоретичні знання для розв'язання певних практичних завдань; формування у кадетів потреби та вміння самостійно поповнювати свої знання.

Розвитку у кадетів мислення, мовлення, фізичних, моральних якостей, військових умінь і навичок, а також індивідуально-психологічних особливостей сприяли класні, позакласні, індивідуальні заняття, дозвіллєва діяльність та перебування у літньому таборі. Одним із головних педагогічних методів був метод привчання.

\section{3. Привчання кадетів до читання}

Суттєве місце у дозвіллі кадетів відводилося позакласному читанню, що сприяло їх морально-естетичному вихованню. Важливе значення мало читання книг як самостійно так і під керівництвом вихователів. В розпорядку дня відводився спеціальний час для обов'язко- 
вого читання від однієї до півтори години, яке не повинно було проводитись безпосередньо перед церковною службою [30, с. 108].

Зауважимо, що прищеплення любові до читання, вивчення літератури у кадетських корпусах представляло собою спеціально організований педагогічних процес. Про вплив та користь читання писав і випускник Петровсько-Полтавського корпусу генерал М. Домонтович: «Користь від нашого читання була загальна і приватна, віддалена і найближча. Розвиваючи у нас художне чуття, допитливість розуму i, взагалі, розширюючи кругозір, читання давало нам і зокрема такі відомості, з якими ми зустрічались у курсах спеціальних класах» [9, с. 452].

Матеріали з історії Петровського Полтавського кадетського корпусу засвідчують якими методами залучали вихованців закладу до читання:

«...в корпус були запрошені: актор В. Успенський, який прочитав кадетам кілька творів російських письменників...Для читання кадетам в 1 та 2 роти виписувались газети «Русский инвалид» та «Правительственниый вестник». Крім недільних читань вихователів, кадетам прочитано: в 3-й роті полковником Ромашкевичем: «Богдан Хмельницький», твір Рогова; «Сльози», Красницького; «Непокупне» i «Ненароком» Польового та «Жук» Бабікова. В 4-й роті підполковником Юркевичем «Про Російсько-Японську війну» і полковником Нікушиним те чи інше читання проводилось...» [26, с. 70-71].

У матеріалах про життя цього корпусу з 1 жовтня 1909 по 1 жовтня 1910 року повідомляється: «Крім Недільних читань вихователів, у 3 та 4 ротах ротними командирами були організовані читання по суботах $\mathrm{i}$ напередодні празників після всенощної. Кадетам 1, 2 і 3 рот при відправленні їх на канікули було видано перелік книг, які рекомендувалось прочитати у відпустці. Для читання кадетами в ротні читальні виписувались наступні видання: в 1 роті «Русский Инвалид», «Правительственный Вестник», «Новое Время», «Русская Старина», «Военный сборник» $\mathrm{i}$ «Полтавский Вестник», в 2 роті: «Русский Инвалид», «Новое Время», «Русская Старина», $\mathrm{i}$ «Полтавский Вестник», в 3 роті «Родник», «Задушевное слово», «Русский Паломник», «Витязь», «Любитель природы», «Маяк» и «Юная Россия», в 4 роті «Путеводный Огонек». В ротні бібліотеки придбано нових книг на 600 р., по 150 р. на роту [27, с. 20$]$. 
З 1907 року було введено обов'язкове позакласне читання святого Письма, що супроводжувалося бесідами й поясненнями. Зверталась особлива увага на забезпечення літературою, кожний кадетський корпус мав фундаментальну бібліотеку [15, с. 207].

Розвиток бібліотек у військово-навчальних закладах йшов за двома напрямкам - формувались бібліотеки фундаментальні (загальні) i ротні. Фундаментальні призначались для використання в наукових цілях і доступ до них було дозволено викладачам, офіцерам, пізніше кадетам старших курсів за рекомендацією та дозволом ротного офіцера. Для решти кадетів книги із спеціального відділу загальної бібліотеки ( він називався «вікова бібліотека»), книги для читання отримували окремі викладачі або ротні командири за рекомендацією викладачів. Таким чином книги спецвідділу тимчасово переходили до ротної бібліотеки, відповідальність за утримання якої покладалась на окремого вихователя [2, с. 20].

Увага до вмісту бібліотек і до читання кадетів та юнкерів з розвитком мережі військово-навчальних закладів стає одним з важливих аспектів виховної роботи. Про це можна судити із затвердженого у 1830 році «Статуту для військово-навчальеих закладів 2-го класу». У ньому немає окремого параграфа, який би регламентував діяльність бібліотек, але параграф 37 глави «Про моральне виховання» проголошує: «Вихователь повинен звертати величезну увагу на вибір читання вихованців, віддаляючи від них все, що може розбещувати уяву, всякі твори, що можуть викликати неприємні судження, навіть і такі книги, які хоча і не включають у себе нічого шкідливого, але не даючи серцю i розуму нічого корисного, шкодять тим, що витрачають безкорисно час і привчають вихованців до такого порожнього читання, після якого важко йому взятися за істинно корисні книги» [33, с. 295].

Нагадаємо, що цей «Статут» був діючим до 1863 року. Інструкція, яка регламентувала роботу бібліотек військово-навчальних закладів, була видана у 1882 році та перевидавалась пізніше [12].

У ній були вміщені правила які раніше закріплювались статутами, наказами і розпорядженнями по навчальних закладах, а також засвоєні на практиці: визначався склад бібліотек військових закладів, вказувались відділи, які повинні бути в них представлені. Оскільки увага до того, що читають вихованці була найпильнішою, то і поповнення віко- 
вих бібліотек було не стихійним. Після затвердження інструкції було затверджено і перелік книг, які можна було придбавати для ротних бібліотек. Це питання вирішувалось колегіально, для чого при Головному управлінні військово-навчальних закладів створили постійну комісію. До неї входили спеціалісти, які повинні були розглядати та схвалювати книги для наповнення бібліотек для читання вихованців військово-навчальних закладів. Книги розділялись на дві категорії: рекомендовані і ті, використання яких може допускатись, їх перелік доводився до відома керівників закладів через періодичні циркуляри. Після затвердження Головним начальником військово-навчальних закладів, видавались каталоги книг для читання вихованцями військово-навчальних закладів [2, с. 20].

Перший такий каталог був випущений у 1885 році і включав перелік книг по семи розділах: духовно-морального змісту, літературного змісту, історії і біографій, військового питання, географії і подорожей, природньо-історичного змісту, журналів та суміші. Книги кожного розділу були представлені за віком читачів [13].

Питання про кадетське читання та різні способи залучення вихованців військово-навчальних закладів до літератури постійно висвітлювались на сторінках журналу «Педагогический сборник», який був науково-педагогічним центром, що об'єднав навколо себе педагогів військово-навчальних закладів. В офіційному розділі видання друкувались матеріали засідань Особливої педагогічної комісії, яка у відповідності до наказу начальника військово-навчальних закладів від 20 жовтня 1866 року була утворена для обговорення загальних педагогічних питань, які стосувались різних військово-навчальних закладів. Так в першому номері журналу за 1867 рік було надруковано циркуляр по військово-навчальних закладах, який визначав які книги і навчальні посібники слід вводити в навчальні плани військових гімназій та пропонував додаткову методичну літературу [37, с. 39-43].

В неофіційній частині збірника питання вивчення літератури на уроках, а також процес позакласного читання кадетів займає постійну рубрику. Серед важливих педагогічних та методичних робіт по цих питаннях слід назвати статті А. Калиновського «Заметки о чтении в младших классах учебно-воспитательных заведений» (1868, № 12), В. Острогорського «Выразительное чтение как учебный предмет сред- 
него образования» (1883, № 9-10), Д. Фомина «Опыт группировки произведений русской и отчасти иноземной литературы для чтения воспитаников первых двух классов кадетских корпусов» (1900, № 9), И.С. Симонова «Что читают старшие воспитанники наших кадетських корпусов» (1905, № 2, 6-9), Н. Жерве «К вопросу о постановке внеклассного чтения в наших кадетських корпусах» (1912, № 2) [30, с. 104-105].

Зазначимо, що кадети старших класів читали твори на військову тематику, молодшим рекомендувалася пригодницька література та вітчизняна класика. Виявлено, що незважаючи на заборону та невизнання української національної культури, вихованцям дозволено було читати твори українських авторів: М.В. Гоголь «Мертві души» $\mathrm{i}$ «Повне зібрання творів», Г.Ф. Квітка-Основ’яненко «Маруся», Т.Г. Шевченко «Кобзар» і «Пісні і думки кобзаря» [14, с. 18, 30, 68].

Цікавими є спогади офіцера-вихователя Петровсько-Полтавського кадетського корпусу, полковника О. Ромашкевича, який звертав увагу читача на той вплив, який мали твори М. Гоголя «для особистого, внутрішнього життя кожного 3 нас, для нашого особистого духовного зростання й удосконалення, для зміцнення в нас почуття любові до добра, правди і краси, для нашого християнського розвитку». О. Ромашкевич зазначав, що за допомогою літератури, зокрема творів М. Гоголя, вихованці засвоювали нові переконання, формували погляди на життя, змінювали напрям думок і почуттів. «Таке ж значення для нашого внутрішнього життя мають твори М. Гоголя. Коли ви читаєте, то не менше насолоджуєтесь його дотепністю, не лише смієтесь над кумедними особами й розмовами, але й переживаєте багато серйозних і піднесених почуттів, ви вчитеся думати й відчувати по-християнськи» [27, с. 34].

Офіцер-вихователь зауважував, що велике місце в естетичному вихованні займає формування у вихованців художнього смаку, пов'язаного зі сприйняттям і переживанням прекрасного. Великого значення в розвитку естетичного виховання О. Ромашкевич надав саме опису рідної природи, який представляв М. Гоголь у своїх творах. «Коли М. Гоголь відображає перед вами красу природи, змальовує дивовижну українську ніч, величний Дніпро, безмежні степи чи старий занедбаний сад - ви мимохіть починаєте жити одним життям 3 природою і 
в ній відчувати дихання вищої, творчої сили, ви пізнаєте Бога. Коли М. Гоголь вводить вас у коло людського життя, $з$ дивовижною яскравістю таланту розкриває перед вами людські характери й почуття, то чисті, піднесені, сміливі, ніжні, зворушливі; то дріб'язкові, низькі, грубі, боягузливі, вульгарні, він викликає в нашій душі новий ряд переживань, ріднить вас із людьми, збуджує у вас співчуття до характерів добрих і прекрасних, огидливість - до вульгарних і низьких. Вас зворушує ніжне почуття материнської любові до молодих синів, що не знаходить належного визнання, вражає мужня рішучість власними руками принести в жертву Вітчизні гарячо-любимого сина, захоплює до сліз мученицька смерть за Вітчизну другого сина» [27, с. 34].

Отже, викладені вище відомості доводять, що естетичному вихованню кадетів у Петровського Полтавського кадетського корпусі надавалась значна увага і воно було на високому рівні. Методика естетичного виховання включала читання (самостійне і групове). Воно передбачало: бесіди, читання творів класиків, педагогічні ситуації, виховне читання періодичних видань 3 наступним обговоренням. Цьому сприяла наявність корпусної та ротних бібліотек, фонди яких складалися з класичної літератури та великої кількості періодичних видань. Офіцери-вихователі та викладачі корпусу плідно використовували рекомендації щодо занять $з$ кадетами читанням, розміщені у нормативних документах та фаховому виданні «Педагогический сборник».

\section{4. Музичне виховання}

Одним із напрямків формування естетичних смаків кадетів було музичне виховання. До проблеми обов'язкового музичного виховання військових, в тому числі і кадетів, одним з перших виявив зацікавленість великий князь Михайло Павлович. У підписаному ним наказі по військово-навчальних закладах говорилось про те, що музика «підносить дух людини, дає ій засіб бути приємною у товаристві, а в сумні хвилини життя служить іноді втіхою». У зв'язку з цим рекомендувалось: вихованцям - дозволити у вільний від занять час займатись музикою, батькам і родичам - компенсувати витрати на їх навчання, кадетському корпусу - створити умови для занять [34, с. 11].

Організаційно навчання співу складалося з викладання основ теорії музики в перших двох класах, а в подальшому, у діяльності кор- 
пусного хору. Обсяг навчального матеріалу був розрахований на два одногодинних уроки співу на тиждень у позакласний час. Слід зазначити, що заняття з молодшими вихованцями складалися зі співу на слух, одночасно з цим, викладали теорію музики. Обидва навчальних компонента велися паралельно і взаємно доповнювали один одного. У першому класі ознайомлення з так званою музичною мовою проходило шляхом співу на слух одноголосних молитов, наспівів світського змісту та інших вправ, що розвивало музичний слух, голос та почуття ритму. Після цього навчали двохголосному співу на слух молитов для середнього регістру голосів. Паралельно кадетів вчили співати по нотах. Починали з назви тонів гами, поступово доходячи до співу гами до мажор з відтінками, з різних ступенів в обсязі відповідного голосу. Закінчували перший рік навчання вивченням головних тризвуків до мажорної гами. У другому класі кадети освоювали спочатку двохголосний, а потім і трьохголосний співи. Паралельно вивчали терміни темпу, мажорні гами з діезами і бемолями, мінорні гами, збільшений i зменшений тризвук [20, с. 119-121].

Логічним продовженням класних занять у молодших класах були вправи в хоровому співі для кадетів різного віку. Кожного учасника хору вчили тримати свою партію і розуміти іï значення в хоровому ансамблі. Вправи велися по частинах - по голосах, по класах, поротно, а також у загальному складі. Для кожної окремо взятої групи визначався один урок на тиждень.

Загальний репертуар хору включав декілька обов'язкових музичних творів. Зазвичай це були гімни, військові, патріотичні і народні пісні, романси і хорові уривки з опер. Кожен кадетський концерт починали і закінчували державним гімном. Засобом підтримання дитячого інтересу до занять вважалось розучування народних пісень, які були відомі вихованцям з дитинства і не потребували особливих зусиль для запам'ятовування. Військові та патріотичні пісні ознайомлювали 3 подіями воєнної історії, іï героями, буднями воїнів. У свою чергу оперні уривки розширювали світогляд вихованців, сприяли ознайомленню із вітчизняною та зарубіжною музичною літературою [31, с. 221-222].

Любов кадетів до музики підтверджують їх спогади. Так, вихованець Полтавського кадетського корпусу П. Волошин згадував: «Ми, українці, завжди були дуже музичні, а кадети корпусу усі без винятку 
були маленькі українці: Стеценки, Павленки, Ващенки... Ми могли всім корпусом співати досить складні музичні твори, що і робили на великих концертах, які вражали гостей. У річницю Полтавської битви весь особовий склад корпусу, розташований на парадних сходах, зміг заспівати дуже важку для виконання кантату, написану в старовинних ладах українською мовою» [5, с. 13].

Заняття співом і музикою нерідко називались необов'зковими, оскільки асоціювалися з відпочинком і розвагами, тобто такими, що не вимагали зусиль розумових і фізичних. Тим не менше, один-два рази у навчальному році у присутності екзаменаційної комісії і запрошеної публіки проводились музичні випробування, в яких брали участь корпусний і церковний хори, духовий і струнний оркестри, окремі кадети-виконавці. У описі життя Петровського Полтавського кадетського корпусу за 1912 рік знаходимо відомості про такі випробування. «18 березня, за прикладом минулих років, в Петровському Полтавському кадетському корпусі відбувалося річне випробування кадетів корпусу по музиці та співу. Після цілорічної роботи програма «випробування» сяє ретельністю підготовки. «Випробування» розпочалось «Урочистою увертюрою» Келера-Бела, виконаною духовим оркестром. Як цей номер, так і попурі із опери «Демон», показали, що кадети 3 любов”ю ставляться до цієї справи. Оркестр звучить потужно, красиво. Прекрасно була виконана кантата М.О. Ажинського «Його обрав Бог». Кантата написана до ювілею Ломоносова на слова Майкова... На завершення всіма кадетами була виконана відома пісня «Два великана» і народний гімн, підтриманий дружним молодим «ура» [27, с. 42].

До вихованців, які брали участь у хорі застосовувались заохочення: безоплатне відвідування спектаклів в імператорських театрах, можливість грати на корпусних інструментах у святковий та канікулярний час, сольний виступ на кадетських концертах, нагородження цінними подарунками: інструментами і рідкісними нотними виданнями, додатковий час до відпустки [11, с. 11-12].

На організацію естетичного виховання в кадетському корпусі впливало й національне походження їх вихованців і наставників. Так, наприклад, на розважальних вечорах обов'язково виконували попурі 3 українських пісень. Цікаво, що українські народні пісні кадети виконували під керівництвом обрусілого німця - капітана К.Ф. Фон-Ка- 
сарта, шанувальника музики й пісні, а особливо популярною у його вихованців була пісня «Закувала та сива зозуля» [10, с. 11].

Важливо зауважити, що під час розроблення програм для ведення позакласних занять у розділі навчання співу і музиці керівництво корпусів $з$ повагою ставилося до народної творчості українського народу. Так, у переліку пісень для кадетських хорів із 56 народних пісень 18 були саме українськими: поряд 3 відомими російськими «Вниз по матушке по Волге» і «Во поле береза стояла» стояли улюблені для багатьох кадетів - українців народні пісні: «Ой на горі та й женці жнуть», «Гуде вітер вельми в полі», «У сусіда хата біла» та інші [20, с. 123-124].

Особлива увага у корпусі надавалась й розважальним вечорам, програма яких завжди попередньо обговорювалась у педагогічному комітеті. Обов'язковими були читання поетичних творів, хоровий спів під акомпанемент, виконання музичних п'єс на різних інструментах, танці, спектаклі. На них були присутні корпусні дами зі своїми дітьми. У своїх спогадах полковник Б. Каховський - офіцер-вихователь Полтавського кадетського корпусу, так описував один із вечорів: «...танцювали кадриль, вальс, польку, мазурку. Останню вихованці дуже полюбляють і танцюють охоче та непогано». Крім цього вечора протягом зими до полтавського корпусу, із відома директора, були запрошені батьки, родичі і знайомі вихованців. 6 грудня, як день відкриття закладу, святкувався урочисто, у цей день завжди був танцювальний вечір. На цих заходах завжди були присутні викладач танців, які слідкував за танцюючими вихованцями. Вечори намагалися зробити більш сімейного характеру, запрошуючи всіх присутніх танцювати і проводити час з вихованцями [21, с. 161].

Отже, музичне виховання вважалося невід'ємною частиною підготовки кадетів і проводилося за двома напрямками, які називалися «спів» і «музика». Ці заняття, з одного боку розвивали музичні здібності, а з іншого були організованим відпочинком для вихованців корпусу. У Петровському Полтавському кадетському корпусі діяли корпусний та церковний хори, духовий та струнний оркестри вихованців, які були постійними учасниками концертів, музичних і танцювальних вечорів, які теж були однією з форм естетичного виховання.

Завдяки застосуванню новаторських підходів до музичного-навчального процесу, участі в ньому професійних музичних викладачів, 
достатньому матеріальному забезпеченню навчальної діяльності в корпусі, були отримані значні результати. Зі стін цього навчального закладу вийшло у своїй більшості музично досвідчене юнацтво, яке знало та любило музику, вміло її слухати та виконувати. Випускниками Петровського Полтавського кадетського корпусу були композитор і диригент Микола Казанлі, український музичний діяч, організатор симфонічного оркестру в Полтаві і Полтавському музичному училищі Дмитро Ахшарумов.

\section{5. Роль літнього табору у вихованні кадетів}

Система виховання в кадетських корпусах була спрямована на формування певних рис характеру у їх вихованців, з одного боку, - суспільно цінних, з іншого, - таких, які б допомогли юнакам адаптуватися в майбутній трудовій діяльності, адже більшість випускників цих навчальних закладів пов'язували своє життя з військовою справою. Сприяло такому формуванню кадетів перебування в літніх таборах. Згідно наказу Головного начальника військово-навчальних закладів табори створювалися для кадетів старшої роти, які перебували в них після іспитів. Літні табори відігравали значну роль у системі військово-фізичної підготовки кадетів.

Тож яким був літній табір Петровського Полтавського кадетського корпусу? Як зазначає I.Ф. Павловський, «табір корпусу розміщений за кілька верст від міста, на полях, де Петро Великий вів боротьбу зі шведами, недалеко від кургану, який зветься Шведською Могилою» [21, с. 74].

Це був перший табір кадетів і він скоріше нагадував дачу, ніж дійсно військовий табір. Тут проводили літній час кадети, які не поїхали на канікули. Ними особливо опікувались, намагаючись як найкраще організувати відпочинок. Вихованці займалися читанням, перекладами 3 іноземних мов, доглядали за садком, який був висаджений у таборі, вчилися складати гербарії, виготовляли чучела із тварин, для них організовувалися пішоходні екскурсії за 5-7 верст від табору; грали в рухливі ігри, займалися гімнастикою, вчилися користуватися топографічними інструментами. Оскільки був літній період і табір був над Ворсклою, вихованців навчали плаванню. Цим керував підполковник, викладач О.О. Туржанський, методика якого була дуже швидко опанована вихованцями [21, с. 158]. 
1853 року імператор Микола І відвідав Полтаву і побував на історичному Полі, бачив залишки укріплень табору Петра I і побажав, щоб це укріплення було реконструйовано. Кадети корпусу впродовж літнього періоду 1853-1854 років під керівництвом свого офіцера, викладача математики I.M. Коллерта відновили укріплення. За розпорядженням імператора було складено особливий журнал, в який занесли план спорудженого укріплення і прізвища кадетів для вічного зберігання в закладі. 1856 року вихованці корпусу у літній табірний період відновили редут на Полі битви. Ці факти вказує у своєму дослідженні Л. Шендрик, посилаючись на О. Ліперовського [38].

Реформа 1882 року, реорганізація гімназії в кадетський корпус вплинули і на табірне життя. Віднині навчання у таборі стало обов'язковим для старших класів (6 і 7 класи). Як зазначалося в Положенні про кадетські корпуси: «В літній період часу виводити кадетів двох старших класів у складі стройової роти до табору, де займати їх військово-підготовчими вправами.» [24, с. 8].

I сам табір змінює своє розташування. Щоб кадетський корпус мав табір на власній землі, єпископ Полтавський Іларіон придбав земельну ділянку і табір перемістився ближче до Сампсоніївської церкви і Братської могили російських воїнів. Завдячуючи тому, що укріплення російської армії Петра І знаходились на території табору Петровського Полтавського кадетського корпусу, вони збереглися у доброму стані, оскільки земля не розорювалася. Й на часі тут збереглися укріплення табору російської армії та у 1973 році встановлено пам'ятний знак на місці командного пункту Петра I [38, с. 221].

Оскільки після реорганізації 1882 року фізичне виховання стає обов'язковим, то і в літній період, у таборі кадети займалися фехтуванням, гімнастикою, плаванням, греблею і управлінням човном, стройовою підготовкою, стрільбою, метанням ядра, списа. Постійно влаштовувалися змагання з означених видів фізичного виховання, переможці нагороджувалися призами, їх імена та імена офіцерів-вихователів заносились до спеціального журналу корпусу [27, с. 73-80].

Розпорядок дня у літньому таборі був наступним: підйом о 7-й годині: прибирання, гімнастика, сніданок; о 8-й - починалися різні роботи у самому таборі; опісля підсніданку до обіду - навчальні заняття, по обіді - відпочинок, різноманітні рухливі ігри; після 
полудня - заняття з плавання, греблі, ловіння риби; в несприятливу погоду - читали, слухали лекції офіцерів-вихователів. Разом з офіцерами-вихователями кадети облаштували тир, в якому стріляли із рушниць, метали дротики. Для ігор кадетам були надані: м'ячі, крокет, два більярда, кегельбан, шашки, шахи, ходулі тощо.

У літньому таборі влаштовувалися змагання і з прибулими гостями. Так, влітку 1913 року на історичному Полі проходили змагання між полтавськими кадетами та вихованцями Чугуївського піхотного училища. Програма змагань була цікава і різноманітна: біг в мішках, біг на ходулях: на двох, на одній, ходіння по хиткому брусу, лазіння по жердині, біг з відрами, наповненими водою, біг з яйцями в ложках та інше. Переможці отримували призи [28, с. 76].

Велика заслуга у розробленні програми літніх таборів О.Д. Бутовського. У майбутньому досвід організації літніх табірних зборів полтавських кадетів, свідком і безпосереднім учасником яких був О.Д. Бутовський, вчений трансформує на всеросійський грунт під час організації «тимчасових літніх курсів» для офіцерів-вихователів кадетських корпусів 1890 року [38, с. 224].

Одним із методів виховання в українських кадетських корпусах означеного періоду був метод привчання. Реалізація цього методу насамперед сприяла формуванню й укоріненню в кадетів однісї з найважливіших в їхній подальшій трудовій діяльності риси характеру такої як дисциплінованість. Завдяки методу привчання майбутнім офіцерам прищеплювалися звичка й уміння дотримуватися дисципліни, адже все їхнє наступне життя мало проходити в умовах військової частини, де повсякденне буття підпорядковане твердо встановленому розкладу й субординації, слідування яким є обов'язковим для всіх членів армійського колективу.

Система виховання в Петровському Полтавському кадетському корпусі була спрямована на формування певних рис характеру. За визначенням С. Гончаренка, характер є сукупністю «відносно сталих індивідуальних психічних рис людини, що виявляються в іiї поведінці й діяльності, ставленні до суспільства, колективу, самої себе», він «зумовлений соціальним буттям особистості, засвоєним соціальним досвідом, що породжує типові риси характеру, які визначаються типовими обставинами життєвого шляху людей у конкретно-історичних умовах» [6, с. 352]. 
Цей напрям роботи демонструє такий факт. У звіті командира роти Купчинського про літні заняття кадетів у таборі за 1912 рік вказується таке: «10) Останню прогулянку кадети здійснили в с. Диканьку, в помістя князя Кочубея (23 версти). Погода сприяла подорожі. О 12 год. 15 хв. кадети прибули в помістя в бадьорому настрої, зробивши по дорозі один великий привал. ...кадети оглядали майстерні в помісті: кузню, слюсарну, столярну, лісопильну. Потім оглянули кінний завод і пивоварний, звідки пішли в поле та любувалися табуном молодих коней. ...О 5 годині дня ходили в парк, на квітники і на метеорологічну станцію, де слухали пояснення агронома про посадку карликових дерев і роботу метеорологічної станції. 31 липня о 6 год. 45 хв. ранку кадети вирушили в табір. Незважаючи на важкі умови шляху (дощ, сильна грязюка, вітер і одягнені шинелі), кадети йшли бадьоро і весело. О 1 год 20 хв. дня прибули до табору, не маючи ні одного відсталого» [28, с. 78-79].

Отже, життя кадетів у літньому таборі було цікавим і насиченим: перебування на свіжому повітрі, загартування, різноманітні фізичні вправи і змагання, екскурсії - все це повинно було підготувати вихованців корпусу до служби в армії. Майбутнім офіцерам прищеплювалися стійкі форми поведінки, пов'язані з організованістю, зібраністю, витримкою. Перебування у літньому таборі Петровського Полтавського кадетського корпусу сприяло формуванню кадетів як всебічно розвиненої особистості.

\section{6. Релігійне виховання}

Актуальним є досвід, накопичений Петровським Полтавським кадетським корпусом у формуванні духовно-моральних переконань його вихованців. Релігійне виховання - стало однією із форм цього напряму роботи корпусу.

Релігійне виховання починалося з першого класу і продовжувалось до випускного. Кожний корпус в Україні мав свою православну церкву 3 настоятелем та дияконом. Кадетів по черзі брали на богослужіння, а спеціальні регенти навчали та керували кадетським хором. Щотижневі відвідування храмів були для вихованців обов'язковими. Молитви читалися й співалися не тільки під час служб. Це робилося щодня в кожній роті перед образами після підйому та перед сном, перед та після кожного прийому їжі в їдальні, перед та після уроків у класах [1, с. 149]. 
Свою внутрішню домову церкву, в ім'я святого Сампсонія странноприємця, день якого - 27 червня співпав 3 днем Полтавської битви (27 червня 1709 року), мав і Петровський Полтавський кадетський корпус [23].

Науковець Греков Ф.В. вказує такий цікавий факт, що «іконостас корпусної церкви був виготовлений в академії мистецтв під час перебування там учнем Шевченка, який намалював ікону цариці Олександри» [7, с. 122-123].

Закон Божий був першою дисципліною, що вивчалася як у кадетських корпусах, так і у військових гімназіях. У «Повчанні для освіти вихованців військово-навчальних закладів» (затверджене Царем Миколою I 24 грудня 1848 року) було вказано, що «Вивчення Закону Божого у військово-навчальних закладах не повинно бути наукою: хай вихованці сприймають його не стільки розумом, скільки серцем. Мета викладання Закону Божого наступна: Утвердження в любові до Бога, в Православній Bipi, в безумовній відданості своєму ГОСУДАPEBI, в безкорисливій любові до своєї Вітчизни, в повній самопожертві обов'язку служби і честі і в усіх християнських доброчесностях: сімейних, громадянських, воїнських» [29, с. 21].

Кадети вивчали: священну історію старого (I клас) та нового (II клас) Завіту, вчення про Богослужіння (III клас), докладний православний катехізис (IV i V класи), історію вселенської та російської церкви (VI і VII класи) [29, с. 23-30].

Військова служба розглядалася державою й церквою як священний обов'язок кожного. На всіх уроках законовчителі керували вихованцями у вивченні молитов, ознайомлювали їх з подіями священної історії, заповідями Господніми й церковного Богослужіння. Повчальні настанови стосовно вихованців вони безпосередньо пов'язували з їх навколишнім життям, поєднуючи зміст бесід як із загальним розвитком дітей та юнаків, так і з релігійними почуттями. Кадети обов'язково відвідували церковні служби: у неділю і у святкові дні - на літургії, напередодні цих днів - на всеношній. Також командування корпусів вживало всіх заходів до того, щоб християнські обов'язки виконувалися вихованцями завжди 3 належною увагою, для чого вихователі були присутні при богослужінні разом з кадетами [32, с. 318].

Вихованець Петровського Полтавського кадетського корпусу, генерал О.Д. Бутовський, більш відомий як член першого складу Міжна- 
родного олімпійського комітету, згадував: «Ми вступали тоді до корпусу набожними дітьми... Наші недільні і святкові дні проходили не так, як тепер. Ми не ходили у відпустку. В суботу ми всі стояли на всенощній, в неділю ми всім складом були присутні га обідні. Тепер у моїх спогадах ці церковні служби здаються мені дуже благоліпними, і я думаю, що це дійсно так і було. Наш законовчитель Іван Сіяльський ...правив 3 якимсь проникливим настроєм... не можу забути його високоурочистого проголошення звучним тенором: «Слава Тобі, який показав нам Світло!» І це було однаково урочисто і хвилююче і в темний зимовий вечір, при слабкому освітленні алтаря, і в світлі весняні сутінки, коли помираючий день кидав свої промені на величний іконостас» [3, с. VII].

Значний влив на формування релігійної свідомості кадетів здійснювали промови священників, які мали глибокий переконливий зміст. О.Д. Ромашкевич у своїх «Матеріалах до історії Петровського Полтавського кадетського корпусу» вказує промову до кадетів священника Четверикова, коли він перший раз здійснював службу у корпусній церкві 17 жовтня 1907 року. Наведемо уривки з неї. «По закінченню Богослужіння о. Сергій сказав наступне слово: «Вступаючи сьогодні в вашу корпусну родину і перший раз здійснюючи 3 вами спільну молитву, я радію, що початок мого спілкування з вами освячується саме молитвою, здійснюється у храмі, біля престолу Божого... Кожен з нас без сумніву знає, що таке релігійні почуття. Кожен з нас ще в ранньому дитинстві відчув насолоду молитви...Але цього мало якими б хорошими і дорогими не були ті чи інші почуття, вони можуть глухнути, якщо на них не буде спрямована наша воля. Виховання волі і самовиховання, робота над собою в християнському напрямі - ось чим повинен займатися кожен з нас з раннього дитинства. Ми повинні уважно слідкувати за своїми намірами, за своїми вчинками і в ім'я Христове не допускати в собі нічого, що суперечить християнській совісті» [26, с. 22-23].

У Петровському Полтавському кадетському корпусі поступово складалися свої традиції щодо цього напрямку виховної роботи. До 1908 року у кожному відділенні була розміщена ікона, створена за рахунок кадетів. 3 переходом кадетів у старший клас ікона переносилась, а по закінченню курсу випускний клас за звичай передавав ікону 
до церкви. За порадою директора випускний клас 1908 року вирішив передати свої ікони новачкам, які вступили до першого класу. 28 серпня 1908 року «Бувші кадети 7 класу, тепер юнкери різних військових училищ, зібрались напередодні свого виводу в ці училища, і представники обох відділень бувшого 7-го класу, звернувшись до новачків 3 хвилюючими промовами, передали їм свої святині. Короткі слова подяки, ще більше загальні сльози розчулення були їм відповіддю...До ікон були прикріплені срібні дощечки зі знаменними словами: «Преемственное благословенне Петровских кадет выпуска 1908 года однокашникам-новичкам на честный труд подготовления к доблестному званию воина» [26, с. 67].

Про цю подію повідомляла читачам і газета «Полтавський голос» за 29 серпня 1908 року [23].

На стіні корпусної церкви були розміщені чорні мармурові дошки 3 викарбуваними на них іменами вихованців корпусу, які загинули на полях битв. 3 перших днів навчання в корпусі десятирічні хлопчики молились за упокій душі своїх старших товаришів, які віддали життя за Батьківщину, молились щиро і з душею, розуміючи, що так може скластися і їхнє життя на обраному ними терені.

Слід зазначити, що досвід релігійного виховання у Петровському Полтавському кадетському корпусі формувався протягом усього часу діяльності навчального закладу. Як свідчить своїми спогадами М. Домонтович свідомість дітей, які вступали на навчання до корпусу була різною, особливо в перші роки його існування. Учнівські страхи, дитячу невпевненість частина вихованців намагалася подолати примітивними символічними діями. Приміром, М. Домонтович згадував свого сусіда по молодшому класу, який вважав хрести з воску на парті надійним засобом не бути опитаним на уроці німецької мови. Це не поодинокий випадок. Кадети приносили на уроки, так би мовити «для моральної підтримки», свічки та ладан [9, с. 460].

Різним було сприйняття кадетами обов'язкового відвідування богослужінь, зокрема на початковому етапі діяльності корпусу. На підтвердження цього, наведемо слова М. Домонтовича:. «Потім, дуже вже ретельно почали дотримуватися всіх свят і водити нас часто до церкви ... У церкві ж ми повинні були стояти на витяжку ... Такий формалізм не забарився дати свої плоди: 3 церкви, досить часто, стали виво- 
дити десятками хибнохворих; після церкви починалися глузування, передражнювання та ін.» [9, с. 461].

Переломною датою в контексті релігійного життя та виховання кадетів став 1845 р., коли «доручено було згори зробити в Полтавському корпусі дізнання про причини прояву серед його вихованців вільнодумства. Не знаю, що з'ясувало це дізнання, від себе можу додати, що в деяких 3 нас релігійний настрій став помітно слабшати саме 3 того часу, як почалася зазначена мною формалістика» [26, с. 461].

Та хоча в діяльності корпусу мали місце наведені факти, все ж основою морального виховання кадетів, безперечно, стало християнство. Служіння цареві й Вітчизні на засадах християнської моралі проголошувалося стрижнем морального виховання. Результатом його мала стати підготовка до життя суворо поміркованого, пов'язаного 3 труднощами, яке, однак, повинно було співвідноситися з повною повагою і живим співчуттям до високого покликання й звання воїна. Відданість військовій службі і високоморальні принципи життя випускників Петровського Полтавського кадетського корпусу підтвердили це.

\section{7. Висновки}

Навчально-виховна робота у Петровському Полтавському кадетському корпусі мала свої особливості. У закладі панувала організація розумової діяльності кадетів, спрямована на активізацію їхнього мислення, використання різноманітних засобів розвитку уваги, що дозволило вихованцям оволодівати міцними знаннями, ставати безпосередніми учасниками навчального процесу, стимулювати інтерес до предмета. Загальна ерудиція викладачів, їхня професійна компетентність, загальнолюдські якості, педагогічна техніка, педагогічна культура виступали умовами, які сприяли формуванню професійної компетентності кадета, потреби в самовдосконаленні його як особистості виховували патріотизм.

Основними напрямами в підготовці вихованців Петровського Полтавського кадетського корпусу до військової служби були: загальноосвітній та спеціальний військовий. Загальноосвітній напрям реалізовувався через зміст навчальних предметів, визначених відповідними навчальними планами та програмами. Упродовж усього терміну навчання вихованці вивчали: Закон Божий; російську мову й словесність; 
іноземні мови, математичні науки, природничу історію, фізику, хімію, космографію, географію, історію, законодавство, малювання, чистописання. Вихованців навчали також музиці (теорія музики, гра на музичних інструментах, хоровий спів, світські твори і духовна музика). До програми навчання вихованців корпусу також було включено: танці (полонез, менует, полька, вальс, мазурка та інші), гімнастичні заняття (гімнастика, фехтування, їзда верхи, плавання). Кадети набували майстерності у роботі зі столярними, токарними і слюсарними ремеслами та в гончарстві.

Суттєву роль у підготовці вихованців Петровського Полтавського кадетського корпусу відігравав спеціальний військовий напрям, основне завдання якого вбачалося у формуванні відданості батьківщині, уміння й бажання ії захищати. Зміст військової підготовки складали: теоретичні (класні) заняття, на яких вивчали артилерію, фортифікацію, тактику, військовий статут, топографію, військову історію; практичні (позакласні) - стройове навчання та військово-підготовчі заняття, індивідуальні навчання з відточення майстерності володіння зброєю, спритності у подоланні перешкод тощо; індивідуально-групові - шеренгове і взводне навчання - рух колонами, осаджування i примикання, зміна напрямку рядами тощо. Вирішенню завдань військової підготовки у поза навчальний час сприяли: польові виходи, спортивні змагання, перебування в літньому таборі, загартовування за будь-яких погодних умов. Військова дисципліна у Петровському Полтавському кадетському корпусі, яка полягала у строгому і точному дотриманні кадетами всіх правил, встановлених тогочасним законодавством, забезпечувалася шляхом суворого дотримування режиму дня, чиношанування, точного і беззаперечного виконання наказів, дотримання порядку.

У Петровському Полтавському кадетському корпусі вдало поєднувалися освіта й виховання, що сприяло вирішенню завдань: релігійного, морального, фізичного, естетичного, трудового. Їх досягненню сприяли: бесіди, привчання, повчання, духовне навіювання; відвідування історичних пам'яток рідного та інших міст, музеїв, братських могил; суворе дотримання статутних правил та норм поведінки; усталені офіційні традиції закладу, пов'язані з ушануванням річниць Петровського Полтавського кадетського корпусу. 
Таким чином, вихованці Петровського Полтавського кадетського корпусу з дитинства привчалися до дисципліни, організованості, завдяки чому гальмувався розвиток негативних якостей і рис характеру. Різнопланове виховання допомагало формуванню особистості кадета.

Сьогодні кадетське виховання здійснюється у військових ліцеях та сучасних кадетських корпусах України. Учні ліцеїв з посиленою військово-фізичною підготовкою та вихованці кадетських корпусів, як і кадети Петровського Полтавського кадетського корпусу, проживають в умовах інтернату з військовим устроєм життя. У цих навчальних закладах також зберегли традицію уніформи, посиленої уваги до військово-фізичної підготовки. Впровадження в освітній процес кращих традицій військової педагогіки є дуже актуальним, оскільки забезпечує не лише грунтовну підготовку майбутніх військових, а й формує високоморальну всебічно розвинену особистість. Особливості навчально-виховної роботи у сучасних закладах початкової військової освіти України буде розглянуто у наступних наукових дослідженнях.

\section{Список літератури:}

1. Балабай М.О. Організація виховної роботи в кадетських корпусах Російської імперії, створених на території українських губерній в середині XIX - на початку XX ст. Збірник наукових прачь Харківського університету Повітряних Сил. 2012. Випуск 2(31). С. 148-153.

2. Бондаренко M.А. Библиотеки военно-учебных заведений XVIII - начала ХХ века и их роль в формировании офицеров. Библиосфера. 2012. № 3. С. 18-25.

3. Бутовский А.Д. Годы моего учения в Петровско-Полтавском кадетском корпусе. Посвящается родному корпусу по случаю его 75-летия, 1840-1915 гг. Пг. 1915. 53 c. URL: http://histpol.pl.ua/ru/?option=com_content\& view=article\&id=3153 (дата звернення: 22.10.2020).

4. Военная педагогика / под общ. ред. О.Ю. Ефремова. Санкт-Петербург, 2008. $640 \mathrm{c}$.

5. Волошин П. Три времени в четырех стенах. Военная быль. 1959. № 34. C. 10-15.

6. Гончаренко С.У. Український педагогічний словник. Довідкове видання. Київ, 1997. 375 с.

7. Греков Ф.В. Краткий исторический очерк военно-учебных заведений: 1700-1910. Москва, 1910. 192 с.

8. Державний архів м. Києва. Ф. 112. Оп. 1. Спр. 284. 26 арк.

9. Домонтович М.А. Полтавский кадетский корпус в первые годы его существования. Исторический вестник. 1890. № 11. Т. 42. С. 444-476.

10.Жук В.Н. Один 3 цікавих навчальних закладів минулих часів (Петровський Полтавський кадетський корпус). Полтава, 1993. 23 с. 
11.Инструкция для обучения пению и музыке в кадетских корпусах. Педагогический сборник. 1889. № 8. С. 11-12.

12.Инструкция по содержанию библиотек военно-учебных заведений, подведомственных главному их управлению. Санкт-Петербург, 1904. 14 с.

13.Каталог книг для чтения воспитанников кадетских корпусов. СанктПетербург, 1885. 72 с.

14.Каталог книг для ротных библиотек кадетских корпусов. СанктПетербург, 1907. 72 с.

15.Коміренко Ю. Становлення та розвиток системи виховання в кадетських корпусах України у другій половині XIX - на початку XX століття. Психолого-педагогічні проблеми сільської иколи. 2012. Випуск 43. С. 202-209.

16. Лалаев М.С. Исторический очерк военно-учебных заведений, подведомственных Главному их Управлению: 1700-1880. Санкт-Петербург, 1880. $464 \mathrm{c}$.

17. Материалы, извлеченные из протоколов военных гимназий за 1867 год. Педагогический сборник. 1868. № 2. С. 590-810.

18. Материалы, извлеченные из протоколов педагогических комитетов и годовых отчетов военных гимназий за 1863-1868 года. Педагогический сборник. 1868. № 1. С. 50-367.

19. Меньшой Андрей Бертельс. Воспоминания. Кадетская перекличка. 1976. № 16. URL: http://xxl3.ru/kadeti/bertels_3.htm (дата звернення: 14.08.2020).

20. Общая программа, распределение времени и наставление для ведения внеклассных занятий в кадетских корпусах. Санкт-Петербург, 1890. 167 с. URL: http://elib.gnpbu.ru/text/obschaya-programma--v-kadetskih-korpusah_1890

21. Павловский И.Ф. Исторический очерк Петровского Полтавского кадетского корпуса (1840-1890). Полтава, 1890. 183 с.

22. Петров П.В., Соколов Н.А. Главное управление военно-учебных заведений. 1802-1902. Исторический очерк. Санкт-Петербург, 1914. ч. III. 215 с.

23. Петровский Полтавский кадетский корпус. URL: http://www.museum. poltava.ua/Poltava/Roundarea/building5/index.htm (дата звернення: 21.10.2020).

24. Положение о кадетских корпусах, высочайше утвержденное 14 февраля 1886 года. Санкт-Петербург, 1886. 94 c. URL: https//www.prlib.ru/item/438011 (дата звернення: 21.10.2020).

25.Райковский В. Л. Военное воспитание. О долге и чести воинской в российской армии: Собрание материалов документов и статей/ сост. Ю.А. Галушко, А.А. Колесников; под ред. В.Н. Лобова. Москва, 1990. С. 261-270.

26. Ромашкевич А.Д. Материалы к истории Петровского Полтавского кадетского клпуса с 1-го октября1907 г. по 1-е октяря 1908 г. Год пятый. Полтава, 1908. URL: http://histpol.pl.ua/ru/?option=com_content\&view $=$ article\&id $=4958$ (дата звернення: 17.10.2020).

27.Ромашкевич А.Д. Материалы к истории Петровского Полтавского кадетского корпуса с 1-го октября 1911 г. по 1-е октября 1912 г. Год девятый. Полтава, 1912. 210 c. URL: http://xxl3.ru/kadeti/p-polt_kk.htm (дата звернення: 17.10.2020). 
28. Ромашкевич А.Д. Материалы к истории Петровского Полтавского кадетского корпуса с 1-го октября 1912 г. по 1-е октяря 1913 г. Год десятый. Полтава, 1913. URL: http://histpol.pl.ua/ru/?option $=$ com_content\&view $=$ article\&id $=4963$ (дата звернення 11.10. 2020)

29. Ростовцев Я.И. Наставление для образования воспитанников военно-учебных заведений: Высочайше утверждено 24 дек. 1848 г. СанктПетербург, 1849. XXIV. 185 c. URL: https://search.rsl.ru/ru/record/01003571850 (дата звернення: 29.09.2020).

30. Седова Е.Е., Пономарева С.В. Чтение в системе воспитания кадетських корпусов. Историко-педагогический журнал. 2014. № 4. С. 103-113.

31. Скрябіна О. Музичне виховання у початкових військових навчальних закладах у другій половині XIX - на початку XX століть. Військова освіта. 2016. № 2. С. 220-225.

32. Тимченко-Рубан И.Р. Из воспоминаний о пережитом. Посвящается товарищам по Павловскому и сослуживцам по Петровскому Полтавскому кадетским корпусам. Исторический вестник. T. XLI. 1890. Июль-август. С. 94-114, 304-333.

33. Устав для военно-учебных заведений 2-го класса / Полное собрание законов Российской империи. 2-е изд. СПб., 1831. Т. 5, ч. 1. С. 290-330.

34. Филаретова С.М. Музыка в повседневной жизни кадетских корпусов России : автореф. дис. ... канд. искусствоведения. Петрозаводск, 2011. 23 с.

35.Центральний державний історичний архів України. Ф. 707. Оп. 23. Спр. 502. 29 арк.

36.Центральний державний історичний архів України. Ф. 707. Оп. 25. Спр. 468. 24 арк.

37.Циркуляр по военно-учебным заведениям. 16 декабря. 1866. № 50. Педагогический сборник. 1867. № 1. С. 39-43.

38. Шендрик Л. Літній табір Петровського Полтавського кадетського корпусу. Полтава: архітектура, історія, мистеитво : матеріали III наукової конференції «Вайнгортівські читання» (Полтава, грудень 2009). Полтава, 2009. C. $218-225$.

\section{References:}

1. Balabay M.O. (2012). Organizatsiya vihovnoyi roboty v kadetskih korpusah Rosiyskoi imperii, stvorenih na teritorii ukrainskih guberniy v seredyni XIX na pochatku XX st. [Organization of educational work in the cadet corps of the Russian Empire, created in the Ukrainian provinces in the mid-nineteenth-early twentieth century]. Collection of scientific papers of Kharkiv University of the Air Force, vol. 2(31), pp. 148-153.

2. Bondarenko M.A. (2012). Biblioteki voyenno-uchebnih zavedeniy XVIII - nachala XX veka i ih rol v formirovanii ofitserov[Libraries of military educational institutions of the XVIII - early XX century and their role in the formation of officers]. Bibliosphere, no. 3, pp. 18-25.

Butovskiy A.D. (1915). Gody moyego ucheniya v Petrovskom Poltavskom kadetskom korpuse. Posvyashchayetsya rodnomu korpusu po sluchayu yego 
75-letiya, 1840-1915 gg. [Years of my studies in the Petrovsko-Poltava cadet corps. Dedicfted to the native corps on the occacion of its $75^{\text {th }}$ anniversary, 1840-1915]. Pg.: tip. M.M. Stasulevicha. URL: http://histpol.pl.ua/ru/?option=com_content\& view $=$ article \&id=3153 (accessed 22.10.2020). (in Russian)

3. Yefremov O.U. (ed.) (2008). Voyennaya pedagogika [Military pedagogy]. Sankt-Peterburg: Piter. (in Russian)

4. Voloshin P. (1959). Tri vremeni v chetyryoh stenah [Three times in four walls]. Military history, no. 34, pp. 10-15.

5. Goncharenko S.U. (1997). Ukrayinskiy pedagogichniy slovnik. Dovidkove vydannya [Ukrainian pedagogical dictionary. Reference edition]. Kyiv: Lybid. (in Ukrainian)

6. Grekov F.V. (1910). Kratkiy istoricheskiy ocherk voyenno-uchebnih zavedeniy 1700-1910 [A brief historical sketch of military schools: 1700-1910]. Moscow: Tip. Vilde. (in Russian)

7. Derzhavniy arhiv Kiyeva. F.112, op.1, spr. 284, 26 ark. (in Ukrainian)

8. Domontovich M.A. (1890). Poltavskiy kadetskiy korpus v perviye godi yego sushchestvovaniya [Poltava Cadet Corps in the first years of its existence]. Historical Bulletin, no. 11, T. 42, pp. 444-476.

9. Zhuk V.N.(1993). Odinz tsikavyh navchalnih zakladivminulih chasiv(Petrovskiy Poltavskiy kadetskiy korpus) [One of the most interesting educational institutions of the past (Petrovsky Poltava Cadet Corps)]. Poltava. (in Ukrainian)

10.(1889) Instruktsiya dlya obucheniya peniyu i muzyke v kadetskih korpusah [Instructions for teaching singing and music in cadet corps]. Pedagogical collection, no. 8 , pp. 11-12.

11. (1904) Instruktsiya po soderzhaniyu bibliotek voyenno-uchebnih zavedeniy, podvedomstvennih glavnomu ih upravleniyu [Instruction on the maintenance of libraries of military educational institutions subordinate to their main department]. Sankt-Peterburg: Tip. V.A. Tihanova. (in Russian)

12.(1885) Katalog knig dlya chteniya vospitannikov kadetskih korpusov [Catalog of books for reading pupils of cadet corps]. Sankt-Peterburg: Tip. M.M. Stasulevicha. (in Russian)

13.(1907) Katalog knig dlya rotnih bibliotek kadetskih korpusov [Catalog of books for company libraries of cadet corps]. Sankt-Peterburg. (in Russian)

14. Komirenko Y. (2012). Stanovlennya ta rozvytok sistemy vyhovannya v kadetskih korpusah Ukrayiny u drugiy polovyni XIX - na pochatku XX stolittya [Formation and development of the system of education in the cadet corps of Ukraine in the second half of the XIX - early XX century]. Psychological and pedagogical problems of rural school, vol. 43, pp. 202-209.

15.Lalayev M.S. (1880). Istoricheskiy ocherk voyenno-uchebnih zavedeniy, podvedomstvennih Glavnomu ih Upravleniyu. 1700-1880 [Historical sketch of military educational institutions subordinate to their Main Department: 1700-1880]. Sankt-Peterburg. (in Russian)

16.(1868) Materialy, izvlechonniye iz protokolov voyennih gimnaziy za 1867 god [Materials extracted from the protocols of military gymnasiums for 1867]. Pedagogical collection, no. 8, pp. 590-810. 
17.(1868) Materialy, izvlechonniye iz protokolov pedagogicheskih komitetov i godovyh otchotov voyennih gimnaziy za 1863-1868 [Materials extracted from the minutes of pedagogical committees and annual reports of military gymnasiums for 1863-1868]. Pedagogical collection, no. 1, pp. 50-367.

18. Menshoy Andrey Bertels (1976). Vospominaniya [Memories]. Cadet roll call, no. 16. URL: http://xxl3.ru/kadeti/bertels_3.htm (accessed 14.08.2020).

19.(1890) Obshchaya programma, raspredeleniye vremeni i nastavleniye dlya vedeniya vneklassnih zanyatiy v kadetskih korpusah [General program, distribution of time and instruction for conducting extracurricular activities in the cadet corps]. Sankt-Peterburg: Tip. M.M. Stasulevicha. URL: http://elib.gnpbu.ru/text/obschayaprogramma--v-kadetskih-korpusah 1890

20.Pavlovskiy I.F. (1890). Istoricheskiy ocherk Petrovskogo Poltavskogo kadetskogo korpusa (1840-1890) [Historical essay of the Petrovsky Poltava Cadet Corps (1840-1890)]. Poltava. (in Ukrainian)

21. Petrov P.V., Sokolov N.A. (1914). Glavnoye upravleniye uchebnih zavedeniy. 1802-1902. Istoricheskiy ocherk [Main Department of Military Educational Institutions. 1802-1902. Historical essay]. Sankt-Peterburg. (in Russian)

22. Petrovskyi Poltavskyi kadetskyi korpus [Petrovsky Poltava Cadet Corps]. URL: http://www.museum.poltava.ua/Poltava/Roundarea/building5/index.htm

23.(1886) Polozheiye o kadetskih korpusah, visochayshe utverzhdyonnoye 14 fevralya 1886 goda [Regulations on cadet corps, imperially approved on February 14, 1886]. Sankt-Peterburg: tip. M.M. Stasulevicha. URL: https://www.prlib.ru/item/438011 (accessed 21.10.2020).

24. Raikovskii V.L. (1990). Voyennoye vospitaniye [Military education]. O dolge I chesti voinskoi v rossiyskoi armii: Sbornik materialov dokumentov i statei [On duty and honor of the military in the Russian army: Collection of documents and articles]. Moskva: Voyenizdat, pp. 261-270.

25. Romashkevich A.D. (1908). Materialy $k$ istorii Petrovskogo Poltavskogo kadetskogo korpusa s 1-go oktiabria 1907 g. po 1-e oktiabria 1908 g. God piatiy [Materials for the history of the Petrovsky Poltava cadet school from October 1, 1907 to October 1, 1908. The fifth year]. Poltava. Elektricheskaia tipografiia G.I. Markevicha. Panskiy riad. URL: http://histpol.pl.ua/ru/?option=com content\&view $=$ article\&id $=4958($ accessed 17.10.2020).

26. Romashkevich A.D. (1912). Materialy k istorii Petrovskogo Poltavskogo kadetskogo korpusa s 1-go oktiabria 1911 g. po 1-e oktiabria 1912 g. God deviatiy [Materials for the history of the Petrovsky Poltava Cadet Corps from October 1, 1911 to October 1, 1912 The ninth year]. Poltava. Elektricheskaia tipografiia G.I. Markevicha. Bulvar Konliarevskogo. URL: http://xxl3.ru/kadeti/p-polt_kk.htm (accessed 17.10.2020).

27. Romashkevich A.D. (1913). Materialy k istorii Petrovskogo Poltavskogo kadetskogo korpusa s 1-go oktiabria 1912 g. po 1-e oktiabria 1913 g. God desiatiy [Materials for the history of the Petrovsky Poltava Cadet Corps from October 1, 1912 to October 1, 1913. The tenth year]. Poltava. Elektricheskaia tipografiia G.I. Markevicha. Bulvar Konliarevskogo. URL: http://histpol.pl.ua/ $\mathrm{ru} /$ ?option $=$ com_content\&view=article\&id=4963 $($ accessed 11.10 .2020$)$. 
28. Rostovtsev Y.I. (1849). Nastavleniye dlia vospitannikov voyenno-uchebnih zavedenii: Visochaishe utverzhdeno 24 dek. $1848 \mathrm{~g}$. [Instruction for the education of pupils of military educational institutions: Supremely approved on December 24 . 1848 g.]. Sankt-Peterburg: tip. Voyen.-ucheb. Zavedenii. URL: https://search.rsl.ru/ $\mathrm{ru} / \mathrm{record} / 01003571850$ (accessed 29.09.2020).

29. Sedova Y.Y., Ponomariova S.V. (2014). Chtieniie v sistiemie vospitaniia kadetskih korpusov. [Reading in the education system of cadet corps]. Historical and pedagogical journal, no. 4, pp. 103-113.

30. Skriabina O. (2016). Muzichne vihovannia u pochatkovih viyskovih navchalnih zakladah u drugiy polovyni XIX - na pochatku XX stolit [Music education in primary military schools in the second half of the XIX - early XX centuries]. Military education, no. 2, pp. 220-225.

31. Timchenko-Ruban I.R. (1890). Iz vospominaniy o perezhitom. Posviashchayetsia tovarishcham po Pavlovskomu i sosluzhivtsam po Petrovskomu Poltavskomu kadetskim korpusam [From memories of the experience. Dedicated to comrades in Pavlovsky and colleagues in Petrovsky Poltava cadet corps]. Historical Herald, T. XLI, pp. 94-114, 304-333.

32. Polnoye sobraniie zakonov Rossiyskoi imprii (1831). Ustav dlia voyennouchebnih zavedeniy 2-go klassa [Charter for military educational institutions of the 2nd class]. 2nd ed. Sankt-Peterburg. T. 5, ch. 1, pp. 290-330.

33. Filaretova S.M. (2011). Muzika v povsednevnoy zhizni kadetskih korpusov Rossii [Music in the everyday life of Russian cadet corps]: author. dis. ... cand. art history. Petrozavodsk. (in Russian)

34. Tsentralniy derzhavniy istorichniy arhiv Ukrainy, f. 707, op. 23, spr. 502, 29 ark.

35. Tsentralniy derzhavniy istorichniy arhiv Ukrainy, f. 707, op. 25, spr. 468, 24 ark.

36. Circular on military educational institutions (December 16. 1866. No. 50). Pedagogical collection, 1867, no. 1, pp. 39-43. (in Russian)

37. Shendrik L. (2009). Litniy tabir Petrovskogo Poltavskogo kadetskogo korpusu [Summer camp of Petrovsky Poltava cadet corps]. Poltava: architecture, history, art: materials of the III scientific conference «Weingort readings》 (Poltava, December 2009). Poltava, pp. 218-225. 